\title{
SOCIO-ECONOMIC ANALYSIS OF POVERTY AMONG ARABLE CROP FARMERS IN PLATEAU STATE
}

\author{
Mailumo S.S.* \\ Federal College of Forestry, Jos, Nigeria
}

Omolehin R.

Department of Agricultural Economics and Rural Sociology, ABU, Zaria, Nigeria

\author{
Ajala M.K. \\ National Animal Production Research Institute, Shika \\ *E-mail: drmailumo247@gmail.com
}

\begin{abstract}
The study analysed the socio economic characteristics and poverty depth among arable crop farmers in Plateau State, Nigeria. Using multi-stage sampling technique, 265 farming households were randomly sampled from 9 communities spread across three Local Government Areas of the three agro ecological zones in the State. Primary data generated from farming household heads were mainly used for this study. The household's socio economic characteristics, income and expenditure dominated the bulk of the data. The data were analysed using Foster, Greer and Thorbecke (FGT) index and Tobit regression. The monthly mean per adult equivalent household expenditure (MPAEHE) was 13,940 . A poverty line of $\$ 2,627$ was estimated, based on this poverty line, the FGT measures show that $42 \%$ of the farming households in the study area were poor. The Tobit regression analysis revealed that the number of years spent in school was significant $(P<0.01)$ while farmer's income and size of farmland were significant $(P<0.05)$. An increase in any of these variables would result to a probability of a decrease in the poverty level of the farmers. Age of the farmers was significant $(\mathrm{P}<0.10)$, implying that a unit increase in the age of the farmers, would result to the probability of increasing poverty. From this study, it is recommended that there is the need for policy makers and managers of poverty alleviation programmes to identify the poor at community levels. Any poverty alleviation programme should be targeted at this group.
\end{abstract}

\section{KEY WORDS}

Socio economic, Poverty, Arable, Crop, Plateau.

Nigeria occupies a land area of $923,768 \mathrm{sq} \mathrm{km}$ while only $33.02 \%$ is arable and 2820 $\mathrm{sq} \mathrm{km}$ is irrigated as at 2003. This means that Nigerian farmers cultivate over 30 million hectares of crops annually, $80-90 \%$ of which are cereals (Mahmood, 2007). It has been shown that most Nigerians directly or indirectly depend on the environment. For instance, more than $55 \%$ of the work force is engaged in agricultural activities with about $70 \%$ of them residing in the rural areas (Mahmood, 2007). Literature is replete with empirical evidence of the linkages between poverty and the agricultural sector. About $70 \%$ of the African poor reside in rural areas and depend on agriculture for their subsistence (IFAD, 2001).

Nigeria's national poverty profile has generally been on the rise since 1980, with two significant dips during 1985-1992 and 1996-2004. Focusing on the most recent surveys (1996 and 2004), the national poverty incidence was 65.6 percent in 1996 and declined to 54.4 percent in 2004. Similarly, in 1996, the poverty depth $\left(P_{1}\right)$ and poverty severity $\left(P_{2}\right)$ were 0.358 and 0.207 , but these decreased respectively to 0.225 and 0.122 in 2004 . The national poverty incidence has however surged higher to 69 percent as at 2010 (NBS, 2011). Estimates of inequality also indicate that Nigeria has more unequal distribution of income than Ethiopia, Madagascar, India, and Niger. Further analysis also suggests that poverty in Nigeria is predominantly a rural phenomenon, with rural poverty increasing from 28.3 percent in 1980 to 63.8 percent in 2004. However, the proportion of the urban poor also rose 
from 17.2 percent in 1980 to 43.1 percent in 2004 . Thus, within rural areas approximately 44.4 percent of households in 2004 could not meet their food expenditure requirements. Another 19.4 percent could meet their food expenditure requirements, but not the minimum expenditure to cover other basic needs (Omonona, 2001). In the case of urban households, 26.7 percent were not able to meet their required food expenditure requirements while 16.4 percent could meet their food expenditure but not other non-food basic expenditure needs.

The Nigerian economy is predominantly agrarian in nature; the pattern of the trend in national poverty is translated into agriculture with 87 percent, 67 percent and 77 percent of the core poor being farmers in 1985, 1992 and 1996 respectively (FOS, 1999a). This seems to follow a global pattern. API (2003) reported that over 70 percent of the world population are farmers living on less than two American dollars a day.

This calls for the need to understand and empirically investigate these links as well as to analyse the relationship between socio economic characteristics and poverty depth of farmers.

\section{METHODOLOGY}

The Study Area. The study was carried out in Plateau State, located in central Nigeria. The State derives its name from the geographical landscape that predominates in this part of the country. The state lies between latitudes $8^{\circ} \mathrm{N}$ and $10^{\circ} \mathrm{N}$, and longitude $7^{\circ} \mathrm{E}$ and $11^{\circ} \mathrm{E}$ of the prime meridian (GTZ, 2010). The altitude ranges from around 1,200 meters (about 4000 feet) to a peak of 1,829 metres above sea level in the Shere Hills range near Jos. The state has a land mass covering nearly $30,913 \mathrm{~km}^{2}(11,935.6 \mathrm{sq} \mathrm{mi})$ and ranked as the $12^{\text {th }}$ out of the 36 states in Nigeria. The state has a population of 3,206,531 based on the 2006 census (NBS, 2009). The projected population by 2011 stands at $3,681,299$ people going by a population growth rate of $2.8 \%$ per annum.

The state comprises 3 agro ecological zones and 17 administrative Local Government Areas, viz: The northern zone consisting of Bassa, Barkin Ladi, Jos East, Jos North, Jos South and Riyom Local Governments. Bokkos, Kanke, Mangu, Kanam and Pankshin Local Government Areas make up the central zone. The local governments of Langtang North, Langtang South, Mikang, Qua'an Pan, Shendam and Wase make up the southern zone.

Sampling Procedure and Sample Size. A multi stage sampling was used to select respondents for the study. One local government area was purposively selected from each of the three agro ecological zones of the state. Qua'an Pan was selected from the southern zone while Bokkos was selected from the central zone. Bassa from the northern zone brought the total number of the local governments to three (3). These LGAs have been shown to be engaged in intensive crop cultivation (PADP, 2000). From each of these LGAs, three communities were randomly selected, making a total of nine communities. The farming communities are; from Qua'an Pan - Namu, Kwalla and Kwande; from Bokkos - Bokkos, Manguna and Mushere while from Bassa - Jengere, Jebu-Bassa and Kwall were selected. The sampling frame was made up of a list of farming households obtained from PADP found in the communities. The simple random sampling method was used to draw at least $10 \%$ from the list to constitute the sample size. The total number of the sample size was 265 . These were selected by the use of the table of random numbers.

Data Collection. For the purpose of this study, only primary data were analysed. The data were collected using structured questionnaires. The questions were structured to elicit answers on the objectives of the study. The data collected include the socio-economic characteristics (educational status, age, household size, size of farm land and farming experience of farmers/respondents). These were measured as follows:

i. Age of respondents: means the age of an individual measured in numerical years

ii. Household size: means the total number of people in the house, which includes wives, children and dependants who reside within the same family and eat from "the same pot". 
iii. Educational status: refers to acquisition of knowledge through formal or informal organized means or through schooling. This was measured as the total number of years spent in school.

iv. Farming experience: refers to the number of years that a farmer has actively undertaken farming as occupation. This was measured in years. interview.

v. Farm size: refers to the total hectarage of land put under cultivation as of the time of

To determine their poverty level, information on both quantifiable and non quantifiable factors affecting income and household expenditure pattern were elicited. These factors include:

vi. Household income and expenditure: household income refers to the disposable cash income which is the total receipt (mainly from the sales of farm produce and other off farm activities) less personal taxes plus gifts earned by members of the household, while household expenditure refers to all spending on goods and services intended for consumption. It includes payment by the household for goods and services supplied, accommodation, natural resources, education, health, transportation, communication, clothing, utility supplies, bills and food.

Analytical Techniques:

The tools used for data analysis to achieve the objectives of the study are the Foster Greer and Thorbeck (FGT) index and the Tobit regression.

FGT Weighted Poverty Measure. The Foster, Greer and Thoebecke (Foster, et al., 1984), weighted poverty index were used for the quantitative poverty assessment is defined mathematically as follows:

$$
P_{\propto}=\frac{1}{n} \sum_{i=1}^{q}\left[\left(z-y_{i}\right) / z\right]^{\propto}
$$

where:

$\alpha=$ the FGT index and takes values 0,1 or 2

$\mathrm{n}=$ total number of households

$q=$ number of households below the poverty line

$Z=$ poverty line

$Y_{i}=$ the MPAEHE of the household in which individual $i^{\text {th }}$ lives

Tobit Regression. The Tobit model is expressed following Tobin (1958). Tobit decomposition framework examined the effect of changes in the explanatory variables $\left(\mathrm{X}_{\mathrm{i}}\right)$ on the probability of being poor and the depth or intensity of poverty could be determined. It was also adopted and used by Olaniyan (2000), Omonona (2001), Adejobi (2004) and Bandabla (2005). The Tobit Model can be mathematically expressed as:

$$
\begin{aligned}
\mathrm{V}_{\mathrm{i}} & =\mathrm{V}_{1}=\beta \mathrm{X}_{\mathrm{i}}+\varepsilon_{\mathrm{i}} \text { if } \mathrm{V}_{1}>\mathrm{V}_{1}{ }^{*} \\
& =\quad \beta \mathrm{X}_{\mathrm{i}}+\varepsilon_{\mathrm{i}} \text { if } \mathrm{V}_{1} \leq \mathrm{V}_{1}{ }^{*}
\end{aligned}
$$

where:

$\mathrm{V}_{\mathrm{i}}=$ the dependent variable, it is discrete when the households are not poor and continuous when they are poor.

$\mathrm{i}=1,2, \ldots, \mathrm{N}_{\mathrm{i}}$, where $\mathrm{N}_{\mathrm{i}}$ is the total number of poor households.

$V_{1}=\quad$ Limited dependent variable, it is the poverty depth/intensity defined as ( $Z$ -

$\left.Y_{i}\right) / Z$, where $Z$ is the poverty line and $Y_{i}$ is MPAEHE

$\mathrm{V}_{1}{ }^{*}=$ the poverty depth when the poverty line $(Z)$ equals the MPAEHE (here $V_{1}{ }^{*}=0$ )

$\mathrm{X}_{\mathrm{i}}=$ vector of explanatory variables

$\mathrm{B}=$ vector of unknown parameters

$\varepsilon_{\mathrm{i}}=$ independently distributed error term. 
The empirical model used for determining socio economic factors that influenced poverty among farming households in Plateau State, Nigeria was specified as:

$$
V_{1}=\beta_{0}+\beta_{1} X_{1}+\beta_{2} X_{2}+\beta_{3} X_{3}+\beta_{4} X_{4}+\beta_{5} X_{5}+\beta_{6} X_{6}+\varepsilon_{i}
$$

where:

$\mathrm{V}_{1}=$ limited dependent variable, it is the poverty depth/intensity

$\beta_{0}=$ constant (autonomous poverty depth)

$\beta_{\mathrm{i}} \quad=\quad$ vector of unknown parameters

$\varepsilon_{\mathrm{i}} \quad=\quad$ independently distributed error term

$X_{i}=$ the independent variables specified as determinants of intensity of poverty and defined as follows:

$\mathrm{X}_{1}=$ Years of formal education of household head

$\mathrm{X}_{2}=$ Household size (number)

$\mathrm{X}_{3}=$ Annual income of household head ( $\left.\mathrm{A}\right)$

$\mathrm{X}_{4}=$ Farm size (hectares)

$\mathrm{X}_{5}=$ Years of experience in farming

$\mathrm{X}_{6}=$ Age of household head (years)

\section{RESULTS AND DISCUSSION}

Poverty Profile. The poverty profile of the farming households which include poverty headcount or incidence $\left(P_{0}\right)$, poverty gap or depth $\left(P_{1}\right)$ and squared poverty gap or severity $\left(P_{2}\right)$ were calculated. The $P_{0}$ for the entire farming households was 0.42 . The relative smallness of this figure when juxtapose by the findings by Yusuf (2000) who reported a poverty incidence of $52 \%$ in Kwara State; Omonona(2001) who reported a poverty incidence of $58 \%$ in Kogi State; Bandabla (2005) who reported a poverty incidence of $50 \%$ in Ibadan metropolis, Oyo State and Patrick (2006) who reported a poverty incidence of $62 \%$ in Borno State may not be unconnected to the report by the NBS (2009) that Plateau State had the least unemployment rate of $7.1 \%$ among the states of the federation in 2008 . This means that $42 \%$ of the farming households in the study area were poor (Table 1). The result shows that $3.4 \%$ of the total households sampled were below core poverty level (i.e people who could not spend more than $\$ 1,313$ a month to buy the basic necessities of life). These were considered as the extreme poor. The result also shows that $27.6 \%$ of the households were moderately poor. Their monthly consumption per person was below the poverty line of A2,627, but more than $\$ 1,313$.

Table 1 - Poverty Profile of Households

\begin{tabular}{ll}
\hline \multicolumn{1}{c}{ Index } & A/Percentage \\
\hline MPAEHE & $\mathbb{3}, 940$ \\
$2 / 3$ (MPAEHE) & 12,627 \\
$1 / 3$ (MPAEHE) & $N 1,313$ \\
Head Count Index $\left(\mathrm{P}_{0}\right)$ & 42 \\
$-\quad \quad$ Core Poor $(\%)$ & 03 \\
$-\quad \quad$ Moderate $(\%)$ & 27 \\
$-\quad \quad$ Non Poor $(\%)$ & 58 \\
Poverty Gap Index $\left(\mathrm{P}_{1}\right)$ & 0.21 \\
Poverty Severity Index $\left(\mathrm{P}_{2}\right)$ & 0.11 \\
\hline
\end{tabular}

In all, the analysis showed that $42 \%$ of the sampled households were relatively poor and could not attain the minimum standard of living; this leaves $58 \%$ of the total households sampled to be non - poor. These were the households with per capita monthly expenditure equal or higher than $\mathbb{2}_{2,627}$. Although the poor are conventionally defined as the population that fall below a certain poverty line, it is assumed that even individuals above the poverty line may suffer from "investment poverty" (Reardon and Vosti 1995). 
The poverty gap index $\left(\mathrm{P}_{1}\right)$, usually referred to as the depth of an average poor person from the poverty line was $21 \%$. This implies that $21 \%$ of the poverty line (A552) was required to bring an average poor person in the study area to the poverty line. The poverty index $\left(P_{2}\right)$ which measures the distance of each poor person to one another was found to be 0.11 . This means that among the poor households, $11 \%$ were severely poor. This shows that the poor households were not equally poor but they vary in their degree of poverty.

Relationship between the Socio Economic Characteristics and Poverty Level of the Households. The regression parameters and diagnostic statistics were estimated using the maximum likelihood estimation (MLE) technique (Table 2). From the maximum likelihood estimates of the Tobit regression (equation 2), the results reveal that sigma $(\delta)$ is 0.2163 with a Z - value of 22.87 and is significant at one percent level. This implies that the model has a good fit to the data and the model as specified, explained significant non-zero variation in factors determining poverty depth.

The result showed that four out of the six listed regressors had significant influence on the poverty depth of the farming household's head. It should be noted that a positive sign on a parameter indicated that higher values of the variables tend to increase the likelihood of poverty depth. Similarly, a negative value of a co-efficient implied that higher values of the variables would reduce the probability of the depth of poverty.

Specifically, educational level of household head, farm income and farm size with negative parameter co-efficients agreed with the a priori expectations. Only one parameter (age of household head) had positive co-efficient which again agreed with the a priori expectations. Household size and years of experience of household were however not significant. The coefficient of education is significant $(P<0.01)$. This implies that one year increase in years of schooling will decreased the probability of poverty depth among farming households. This may be attributed to the fact that educated household heads have the tendency to adopt improved farming techniques better and faster than the uneducated ones. This in turn raises the productivity and incomes of the educated heads with subsequent improvement of welfare amongst them.

The coefficient of farm income is significant $(\mathrm{P}<0.05)$ implying that a unit increase in farm income would decrease the probability of poverty by $75 \%$. This is because higher income tends to bring about welfare improvement hence reduction in poverty levels. Results are consistent with findings by Etim (2007) who reported a similar finding in his study on determinants of rural poverty among broiler farmers in Uyo. The coefficient of farm size is significant $(\mathrm{P}<0.05)$ implying that a unit increase in the farm size will result in a probability of reducing the poverty depth of the farming households by $65 \%$. This is obvious because ceteris paribus the expectation is that an increase in farm size should result in a concomitant increase in output, and consequently income.

The regression coefficient for age of farming household head is 0.0027 , meaning that a year increase in the age of household head will lead to an increase in poverty depth. This is attributable to the fact that older farmers are less receptive to the adoption of farm improvement techniques.

\section{CONCLUSION}

The arable crop farming households in the study area were fairly poor requiring a monthly income of $\$ 552.00$ to bring them to the poverty line. Specifically, educational level, income of household, farm size and age had significant influence on poverty depth of farming households.

Based on the findings of this study, the following policy measures aimed at reducing poverty are recommended:

1. There is the need for policy makers and managers of poverty alleviation programmes to identify the poor at community levels so as to direct poverty programmes and projects towards them.

2. Policies that will provide education to the farming households are recommended. To this end, entrepreneurial and environmental education should be availed to the farmers. 


\section{REFERENCES}

1. Adejobi, A. O. (2004). Rural Poverty, Food Production and Demand in Kebbi State, Nigeria. Ph.D. Thesis, Department of Agricultural Economics, University of Ibadan. 130Pp

2. Alliances, Partnership and Integration (API) (2003). Cornerstone for Achieving the Millenium Development Goals. High Level Segment Monterrey Bridge Coalition.

3. Bandabla, T. (2005). Comparative Study of Statistical Distribution and Efficiency of some Poverty Estimators in Ibadan North-East Local Government Area, Oyo State, Nigeria. M.Sc Thesis, Department of Mathematical Sciences, College of Natural Sciences, University of Agriculture, Abeokuta. Pp. 14-91.

4. Etim, N.A. (2007). Analysis of Poverty status of Rural Farm Households in Akwa lbom State, Nigeria. Unpublished Ph.D. Dissertation, Department of Agriculture Economics, Michael Okpara University of Agric, Umudike, Abia State

5. FOS (1999a). Poverty Profile for Nigeria 1980-1996. Federal Office of Statistics. Abuja, Nigeria. Pp 12-15.

6. Foster, J., J, Greer and E. Thorbecke (1984). A Class of Deomposable Poverty Measures. Econometrica 52: $761-766$

7. German Technical Cooperation (GTZ) (2010). A Profile of the Plateau State Economy. Baseline Survey Report. July, 2010

8. IFAD (1992). Soil and Water Conservation in Sub-Saharan Africa: Towards Sustainable Production by the Rural Poor. A report prepared for the International Fund for Agricultural Development. Amsterdam: Center for Development Cooperation Services, Free University.

9. Mahmood, Y. Y. (2007). Agricultural Inputs Constitute the most critical constraint in Agricultural Production and Economic Growth in Nigeria. Lead Paper presented at the $20^{\text {th }}$ National Conference of the Nigerian Association of Agricultural Economists (NAAE) held at the Abubakar Tafawa Balewa University, Bauchi. $6^{\text {th }}-9^{\text {th }}$ November.

10. National Bureau of Statistics (NBS) (2009). Social Statistics in Nigeria-2010

11. National Bureau of Statistics (NBS) (2011). Social Statistics in Nigeria-2012

12. Olaniyan, O. (2000). The Role of Household Endowments in Determining Poverty in Nigeria. A Paper presented at the World Bank DFID Workshop on Mainstreaming Environment in Poverty Planning. Abuja, September 25-27.

13. Omonona, B. T. (2001). Poverty and its Correlates among Rural Farming Households in Kogi State, Nigeria. Ph.D. Thesis, Department of Agricultural Economics, University of Ibadan. Pp 61-237.

14. Patrick, V. K. (2006). Poverty Profile and its Determinants among Farming Households in Borno State, Nigeria. Ph.D Thesis, School of Postgraduate Studies, University of Maiduguri. Pp 1-27

15. Plateau Agricultural Development Programme (2000). House Journal. October, 2000.

16. Reardon. T. and Vosti, S. A. (1995). Links Between Rural Poverty and the Environment in Developing Countries: Asset Categories and Investment Poverty. World Development, $23(9): 1495-1506$.

17. Tobin, J (1958). Estimation of Relationships for Limited Dependent Variables. Econometrica. 12 (7): 26-32

18. Yusuf, T. M. (2000). Socio-Economic Analysis of Poverty Level among Rural Dwellers in Kwara State, Nigeria. M.Phil thesis, Department of Agricultural Economics, University of Ibadan, Nigeria. 